\title{
An ontological exploration of change and constancy
}

\begin{tabular}{|c|c|}
\hline $\begin{array}{l}\text { Author: } \\
\text { Ananka Loubs }\end{array}$ & \\
\hline $\begin{array}{l}\text { Affiliation: } \\
{ }^{1} \text { School of Phi } \\
\text { North-West U } \\
\text { Potchefstroon } \\
\text { South Africa }\end{array}$ & $\begin{array}{l}\text { osophy, } \\
\text { niversity, } \\
\text { Campus, }\end{array}$ \\
\hline $\begin{array}{l}\text { Corresponde } \\
\text { Ananka Loubs }\end{array}$ & $\begin{array}{l}\text { ice to: } \\
\text { er }\end{array}$ \\
\hline $\begin{array}{l}\text { Email: } \\
\text { ananka.loubs }\end{array}$ & r@nwu.ac.za \\
\hline $\begin{array}{l}\text { Postal addres } \\
\text { Private Bag X } \\
\text { Potchefstroon } \\
\text { South Africa }\end{array}$ & $\begin{array}{l}\text { : } \\
\text { 2520 }\end{array}$ \\
\hline $\begin{array}{l}\text { Dates: } \\
\text { Received: } 11 \\
\text { Accepted: } 28 \\
\text { Published: } 12\end{array}$ & $\begin{array}{l}\text { pr. } 2013 \\
\text { Dct. } 2013 \\
\text { Dec. } 2013\end{array}$ \\
\hline $\begin{array}{l}\text { How to cite th } \\
\text { Loubser, A., } 2 \\
\text { ontological ex } \\
\text { change and cc } \\
\text { Koers - Bullet } \\
\text { Scholarship } 7 \\
\text { \#2108, } 8 \text { page } \\
\text { dx.doi.org/10 } \\
\text { v78i2.2108 }\end{array}$ & $\begin{array}{l}\text { is article: } \\
13, \text { 'An } \\
\text { ploration of } \\
\text { nstancy', } \\
\text { n for Christian } \\
(2), \text { Art. } \\
\text { s. http:// } \\
4102 / \text { koers. }\end{array}$ \\
\hline $\begin{array}{l}\text { Note: } \\
\text { This article is } \\
\text { to Professor J } \\
\text { Venter, whose } \\
\text { greatly benefi } \\
\text { his knowledg } \\
\text { Socratic philo }\end{array}$ & $\begin{array}{l}\text { dedicated } \\
\text { J. (Ponti) } \\
\text { students } \\
\text { tted from } \\
\text { of the pre- } \\
\text { ophers. }\end{array}$ \\
\hline $\begin{array}{l}\text { Copyright: } \\
\text { (C) 2013. The } \\
\text { Licensee: AOS } \\
\text { OpenJournals } \\
\text { is licensed un } \\
\text { Creative Com } \\
\text { Attribution Lic }\end{array}$ & $\begin{array}{l}\text { IS } \\
\text { Ihis work } \\
\text { ler the } \\
\text { nons } \\
\text { ense. }\end{array}$ \\
\hline Read online: & \\
\hline 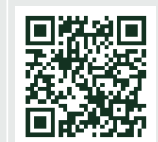 & $\begin{array}{l}\text { Scan this QR } \\
\text { code with your } \\
\text { smart phone or } \\
\text { mobile device } \\
\text { to read online. }\end{array}$ \\
\hline
\end{tabular}

The history of philosophy presents a variety of viewpoints regarding the ontological primacy of either change or constancy. Some views regard change as foundational, to the point where constancy is denied (e.g. Heraclitus). Other views regard constancy as so important, that change becomes unthinkable (e.g. Parmenides). The apparent dialectical tension between the different conceptions demands an ontological clarification of these issues. This study illustrates and evaluates the relationship between change and constancy in the viewpoints of various philosophers and scientists throughout history. This is done by appropriating a reformational insight that change and constancy exist in cohesion. The study finds that the relationship between change and constancy is not dialectical, but rather one of integration, seated in irreducible primitive domains (modalities). The purpose of the article is twofold (1) to show that change and constancy cannot be reduced to one another but can only exist in a relationship of coherence and (2) to contribute a systematic clarification of framework change in terms of the relationship between change and onstancy on the ontological level.

'n Ontologiese verkenning van verandering en konstantheid. Die geskiedenis van filosofie vertoon ' $n$ verskeidenheid van standpunte aangaande die ontologiese voorrang van óf verandering óf konstantheid. Sommige beskouings aanvaar verandering as fundamenteel, tot die punt waar konstantheid ontken word (bv. Heraklitus). Ander beskouings aanvaar konstantheid as so belangrik, dat verandering ondenkbaar word (bv. Parmenides). Die oënskynlike dialektiese spanning tussen die verskillende konsepsies vereis 'n ontologiese uitklaring van die kwessies. Hierdie studie illustreer en evalueer die verhouding tussen verandering en konstantheid in die standpunte van verskeie wetenskapsfilosowe deur die geskiedenis. Dit word gedoen deur 'n reformatoriese insig aan te neem, naamlik dat verandering en konstantheid in 'n kohesie bestaan. Die studie vind dat die verhouding tussen verandering en konstantheid nie dialekties is nie, maar eerder een van integrasie, gesetel in onreduseerbare primitiewe domeine (modaliteite). Die doel van die artikel is tweeledig (1) om te toon dat verandering en konstantheid nie tot mekaar gereduseer kan word nie, maar in 'n verhouding van koherensie bestaan en (2) om 'n sistematiese uitklaring van raamwerkverandering, in terme van die verhouding tussen verandering en konstantheid op die ontologiese vlak, by te dra.

\section{Orientation}

In epistemic frameworks, change and constancy occur according to a pattern. This pattern reflects the irreducibility of coherents (modalities), where change and constancy exist in cohesion. As a result, change can never be completely random or absolute.

This central theoretical assumption underlies a research project discerning a level of consensus regarding the characteristics and functions of epistemic frameworks (Loubser 2013), as well as the factors shaping framework change and the relationship between these factors (Loubser in press). A further part of this project tries to achieve clarity on how framework changes occur (Loubser 2012). Framework changes can, for instance, be conceptualised as being either constrained, predictable and even predetermined or random, unpredictable and free from constraints. Some conceptions attempt a synthesis between the more radical positions. At an earlier phase of the research project the need for an ontological exploration of change and constancy and of substantiation of the main thesis (Loubser 2012) was announced.

In recent philosophy, some conceptions seem to regard change as foundational, to the point where change becomes the only constant. ${ }^{1}$ The conceptions where change is everything and constancy denied can be traced from antiquity (Heraclitus Fr. 12, 49a) ${ }^{2}$ and are also popular in

\footnotetext{
1.I am referring to this group of philosophers as an example, but will not deal with them here. I have already mentioned them in other articles (Loubser in press, 2012).
}

2.The numbering of the fragments is in accordance with the notation in Diels and Kranz (1959-1960). 
postmodernity. They do, however, harbour some problematic internal incoherence. In order for change to be recognised, some kind of constancy must be present (Strauss 2005:225) and the idea that change itself becomes the only constant is therefore rather paradoxical. Other conceptions regard constancy as fundamental to the point where change becomes unthinkable (Parmenides Fr. 2, 6, 7, 8). The apparent dialectical tension between these different conceptions of change and constancy has its roots in antiquity and demands an ontological clarification of these issues.

This brings us to the problem statement of the current article: What is the ontological relationship between change and constancy?

The present investigation proceeds by evaluating a few different ontological conceptions of the relationship between change and constancy in antiquity. Since the issue appears to be still problematic in philosophy, a few modern and postmodern conceptions are considered in addition to the more ancient examples. ${ }^{3}$ This article does not attempt to provide a complete history of the idea, but merely shows that some problems do not die off easily and that some basic trends seem to repeat themselves.

I will argue (with Strauss) for a position where change and constancy go hand in hand, because they are both rooted in primitive domains (modalities) which are irreducible. Change is based on the physical aspect of reality and constancy is rooted in the kinematic aspect (Strauss 2009:164-167). Should we relate this ontological principle to epistemic frameworks, it would appear that they do not change absolutely or arbitrarily, but rather have some kind of plasticity (Loubser 2012).

In the following sections I explore the relationship between change and constancy in Greek philosophy, whilst also paying some attention to the theme of unity and diversity in order to sketch a broader picture and to show how all these issues are interrelated.

\section{Change and constancy in Antiquity Thales}

According to Allen (1966:1) every history of philosophy begins with Thales. This article happens to begin with the opinions of Thales as well, since his philosophy serves as the framework of beliefs which gave rise to ancient thought about the nature of change and constancy.

Thales's pronouncement that the source of all things is water means that (1) all things must have a source and (2) that this source is singular (i.e. one thing) (Allen 1966:1-2). From these two assumptions, it follows that:

the universe is bound to a single principle, the primordial water, by a single relationship, that of derivation' and that 'nature is one whole, with unchanging ways of its own, to be accounted for in terms of a unitary principle of explanation. (Allen 1966:2)

3.The most important philosophers and scientists who debated these issues are included Of course there are other important philosophers of science, but they are discussed elsewhere (Loubser in press, 2012).
For Thales, therefore, the nature of the world is singular, holistic and constant. Although the primordial water was 'alive' and therefore 'capable of spontaneous movement', so that it becomes the 'source of movement' in the world (Allen 1966:2), Thales does not give an explanation of how this singular source could change to give rise to diversity in the world. The question about change was first posed by Anaximander: 'How is the qualitative diversity of the world to be reconciled with the primordial unity of its source?'

\section{Anaximander}

In order to address this question, Anaximander raises an important objection to Thales. For Thales, the primordial element is simultaneously unbounded and water. Water (the wet) stands in a relationship of opposition to other entities that embody the dry. If water were to be unbounded, its opposite would cease to exist (Allen 1966:2).

Anaximander proposes that the primordial principle (the Unbounded) is not to be associated with any sensible opposite, nor does it have any characteristics that can be found in the world of sensory experience. The Unbounded is internally undifferentiated (Allen 1966:2-3).

Furthermore, Aristotle ${ }^{5}$ interprets Anaximander's Boundless to be a mixture of all the sensible opposites (water, air, fire and earth) so that 'the opposites fuse in it' and 'it is itself of no determinate sort, a thing which is no kind because it is all kinds' (Allen 1966:3). According to Anaximander, the Nonlimited is 'everlasting and ageless' (Fr. 2) as well as 'immortal and indestructible' (Fr. 3; cf. Freeman 1971:19) and therefore it is constant.

Anaximander's answer to the question about change is that the different elements (or opposites) separate from the original material and that these opposing elements then 'war' upon one another (Fr. 1). This enmity between the opposites causes a pendulum dynamic (where one opposite, encroaching on the domain of the other, is turned into the other, and vice versa). This cycle is kept in balance by Time, so that the world is in equilibrium (Fr. 1; cf. Allen 1966:3). In this way, although constancy still prevails in his philosophy, Anaximander tries to account for change.

Anaximander is not the only philosopher to propose an answer to the question about change, and a different conception can be found in the thought of Anaximenes.

\section{Anaximenes}

For Anaximenes, the primordial unity is to be identified with a substance (air, mist or breath) and everything else is made out of this material (Fr. 2). Diversity in the world occurs when this primary substance undergoes change of a quantitative nature. This means that qualitative diversity is dependent on the quantitative variation (thickening and thinning, 4.Anaximander's objection to Thales is reported by Aristotle Physics $204 \mathrm{~b} 24$. 5.See Aristotle Physics 187a 12; cf. Allen (1966:31). 
condensation and rarefaction) of the primary substance (Allen 1966:4). According to Anaximenes, air (when made finer) becomes fire or (when made thicker) wind. When air is made thicker still, it progressively becomes cloud, water, then earth, stones and everything else (Freeman 1971:33).

Anaximenes believes, like Thales, that the primary substance is ensouled and this is the cause of motion in the world (Allen 1966:4). Interestingly, for Anaximenes, motion is eternal, but change comes about through it. The primary substance (air) is revealed by motion and is always in motion, for 'things that change do not change unless there be movement' (Freeman 1971:33-34). I will come back to change and constancy in relation to energy and movement later (see below), since it appears that in Modernity movement is associated with constancy rather than change.

\section{Heraclitus}

Like Anaximander, Heraclitus espouses a principle of isonomy that maintains balance in the world process. In the case of Heraclitus, this principle is called 'logos' and is identified with a sensible element, namely fire (Fr. 30; cf. Allen 1966:10). As the first principle of knowledge, the 'logos' has connotations of proportion, measure and pattern. For Heraclitus, however, the 'logos' also represents the first principle of existence: it is the 'unity of the world that sustains it as a process' (Fr. 1; cf. Allen 1966:10). The 'logos' maintains the balance between diverse and conflicting opposites in 'strife'. This balance differs from the equilibrium brought about by Time in Anaximander. According to Allen (1966:10), Anaximander's Time produces equilibrium in a cyclical alteration of excess, whereas the 'logos' in Heraclitus maintains the balance at every given moment. Since the balance is continuous, the opposites being drawn apart are drawn back together at the same time and thus they are being maintained, constantly, in equal measures (Allen 1966:10). ${ }^{6}$ This means that the world process, for Heraclitus, is a circle and that movement in any direction around the circle is continually balanced by movement in the opposite direction (i.e. the way up and the way down happen simultaneously: Fr. 60). The opposites, then, become in a sense the same (Fr. 88; cf. Allen 1966:10-11).

Vollenhoven (2005a:35) emphasises the point further: the two processes do not follow one another, but rather happen simultaneously, so that the continuation in the world is a matter of 'the continual running into each other of two simultaneous streams'. ${ }^{7}$ In the first place, this type of thinking is contradictory. Because the world is self-contradictory, 'the knowledge that describes this world cannot acknowledge as norm principles that would exclude contradictions in thinking' (Vollenhoven 2005a:35). Secondly, because the origin of all things is eternally active fire, Heraclitus is a monist. This leads Vollenhoven (2005a:35; cf. 2005b:92) to describe Heraclitus's thought as a form of contradictory monism.

6. Heraclitus uses the metaphor of the bow (or lyre) to describe this back-stretched connection (Fr. 51; cf. Allen 1966:10).

7.For Vollenhoven (2005a:35), the term 'coincidentia oppositorum' [coincidence of opposites] is eminently suited to this concept.
Although the 'logos' itself is constant (Allen 1966:11), the emphasis in Heraclitus's world is very much on change (Fr. 91). Both Plato and Aristotle describe this as the doctrine of perpetual flux where 'all things change and nothing remain at rest' ${ }^{\prime}$ The first reaction against this doctrine is provided by Parmenides.

\section{Parmenides}

In Parmenides's view, the belief in the reality of the physical world (of plurality and change) is unsatisfactory and is to be substituted by the belief in One Being. The latter is unchanging, ungenerated, indestructible and spherical (Fr. 7, 8; cf. Allen 1966:12). His justification for belief in the One Being is demonstrated in the poem, Way of Truth, by reference to a disjunction, which can be reduced to 'It is or It is not'. The first disjunct is the 'way of true inquiry', whereas the second is the 'unthinkable, unknowable, not to be uttered'; and since thinking and being share the same ontological status (for Parmenides), the second disjunct is to be wholly rejected (Fr. 2; cf. Allen 1966:11).

In contrast to the 'way of true inquiry', Parmenides (Fr. 6) also refers to the 'way of mortal opinion'. The latter presupposes the world of nature as having contents which 'come to be and cease to be' and thus can be reduced to: 'It is and is not'. For Parmenides, the 'way of mortal opinion' is also to be rejected, again on the grounds of the original disjunction (Fr. 8; cf. Allen 1966:12). This means that Parmenides draws a distinction between appearance and reality as well as between knowledge and opinion. In the end, plurality and change are rejected in favour of constancy.

It would appear as though, at the beginning of the fifth century, Greek opinions regarding the relationship between change and constancy are rather polarised. On the one hand, Heraclitus emphasises change, whereas, on the other, Parmenides argues that constancy has ontological primacy. It is not surprising, then, that the reaction to this situation included attempts to synthesise the two opposing positions. According to Allen (1966:14-15), the main challenge after Parmenides was to reconcile the sensible world (of plurality and change) with criteria for reality that it cannot satisfy. These criteria include that the world should be intelligible and therefore free from generation and destruction (i.e. change).

\section{Empedocles: An attempt at integration?}

The proposal from Empedocles rests on the notion that certain elements are constant (satisfying the criteria of reality) and that change occurs when these elements are rearranged (Allen 1966:14-15). Like Parmenides, Empedocles denies the possibility of generation and destruction and accepts the existence of a holistic 'Sphere of Being'. Contrary to Parmenides, however, Empedocles conceives the Sphere as full of sensible opposites (the hot, the cold, the wet and the dry). Change occurs when these constant qualities rearrange 8.See Heraclitus Fr. 12; Plato Cratylus 402 a and Aristotle Physics $253 \mathrm{~b} 9$. 
within the Sphere (Fr. 17; cf. Allen 1966:15). The arrangement of the qualities occurs continually under the compulsion of the cosmic forces of Love and Strife. This means that the various compounds (complex substances of the world) come to be and pass away, but simultaneously the primary qualities constituting the substances remain the same (Fr. 17; cf. Allen 1966:15). Vollenhoven, however, does not regard Empedocles's philosophy of change and constancy as an attempt at integration. He (2005a:35, 2005b:127-128) classifies Empedocles as a dualist and a structuralist, ${ }^{9}$ inclined to constancy (cf. Olthuis \& De Graaff 1978:20-21).

\section{Evaluation}

The natural philosophers can broadly be divided into two groups. The first group proceeds from an original unity (monism). Duality and plurality are still recognised, but must be explained in terms of the original unity and are therefore seen as secondary (Vollenhoven 2005a:33). In this group, we may place, for instance, Thales, Anaximander, Anaximenes and Heraclitus. The second group begins with more than one origin (dualism). Here, two or more equally original (and correlative) causes need to come together in order to give a secondary explanation for unity (Vollenhoven 2005a:33). Parmenides and Empedocles may be placed in this group.

Vollenhoven neatly distinguishes the issue of unity and multiplicity (monism and dualism) from the issue of change and constancy. In fact, both monists and dualists can be inclined to cosmogonic or structuralist thought. One should grant that monists are more often inclined to cosmogonic philosophy, whilst dualists and pluralists are inclined to structuralism. The reason for this seems to be a search for 'balance' (Olthuis \& De Graaff 1978:21-22). Yet there are monists who are structuralists and dualists who choose cosmogonic thinking.

With regard to the main problem statement of the article, ancient thought seems to be polarised into positions giving ontological primacy either: (1) to constancy or (2) to change. Between these two poles there also seems to exist a third position (3) attempting an integration of positions (1) and (2). According to the classification of Vollenhoven (2005a:35), this does not amount to a true integration, and in his method he keeps using only two categories: structuralist and cosmogonic philosophies.

The members of group (1) include Thales, Anaximander, Anaximenes and Parmenides. For Thales, nature is constant and no explanation of how this singular substance could change is given. Anaximander regards the primary principle as everlasting and indestructible (and therefore as constant) and defines change as the 'separation' of different opposites from this original material. The primary substance for Anaximenes remains constant, so that change is only understood in terms of qualitative variation (thickening and thinning, condensation and rarefaction) of the primary substance. However, in Parmenides, group (1) acquires its most radical proponent. He rejects change for belief in the One Being, which is absolutely unchanging.

With regard to position of group (2), the thought of Heraclitus places the emphasis very much on change. For Heraclitus, the first principle ('logos') maintains a balance between diverse and conflicting opposites. This means that the world process is in continuous flux.

In the next section, we find the continuation of some of these issues in modernity and postmodernity.

\section{Change and constancy in modernity and postmodernity An introductory overview}

In the previous section, we have seen various ancient conceptions giving ontological primacy to either change or constancy. Debates on these dilemmas seem to be perennial in the history of philosophy and, of course, continued through the Middle Ages. This article, however, forms part of a research project (Loubser 2012, 2013, in press) investigating more contemporary trends and does therefore not provide a complete historical overview.

Focusing on more recent examples, we again find conceptions emphasising change, to the point that it becomes the only constant (e.g. in Darwin, as well as some popular postmodern conceptions). Other conceptions may regard constancy as being fundamental to the point that change is denied. This can lead to positions that grant ontological primacy to constancy to the extent that change becomes unthinkable, for example in the viewpoints of Von Varga (1953:59-61). The apparent dialectical tension between the different conceptions of change and constancy has also given rise to contemporary attempts at finding 'patterns' in changes. One such example can be found in the work of Gerald Holton.

Holton (1978:8) finds elements (themata) that function to constrain, motivate, guide and even polarise scientific research and scientists. This means that there are constant themes in scientific concepts, methods, problems and hypotheses. Even though the themata function at an epistemological, rather than the ontological level, we can infer that they tell us something about the world through their importance in science. Moreover, Holton (1978:10) finds that the number of themata is limited (in fact, very small) with new themata being added only very rarely. This means that the themata are very persistent and that they fare very well in newly elaborated contexts.

In this project we have often dealt with work of philosophers of science. However, the work of some scientists themselves also seems to contain a polarised notion of either change, or constancy. In the next two sections, we look at examples in the legacies of Charles Darwin and Albert Einstein. 


\section{The importance of change in the work of Darwin}

In his work On the origin of species, Charles Darwin (1869:92) defined 'natural selection' as the 'preservation of favorable variations, and the destruction of injurious variations'. According to Darwin (1869), variations that are inert would not be affected by natural selection but would be:

left as a fluctuating element, as perhaps we see in certain polymorphic species, or would ultimately become fixed, owing to the nature of the organism and the nature of the conditions. (p. 92)

Vollenhoven (2005b:96-97) regards Darwin as a monist and a geneticist. With regard to change and constancy, Darwin seems to hold that the natural (biological) world is inherently changeful ${ }^{10}$ and that only the 'fittest' survive. This has led neo-Darwinism to regard the action of two phenomena, that of mutation and natural selection to occur in tandem (Strauss 2009:110). Since mutation normally occurs to the organism's detriment, only when the aforementioned phenomena act in tandem can the disadvantaged living entity emerge as the advantaged.

According to Strauss (2009:110-111), the role attributed to mutation and natural selection support the main thesis of neo-Darwinism, namely the assumption that the only reality within 'living' nature is change. Strauss (2009:110111) criticises this assumption by stating that 'only when mutation and natural selection are operating as a constant (conditioning) law for the existence of living entities, is it possible to account for the changefulness of the latter'. His point is that the law-effect of mutation and natural selection is supposed to be constant and therefore not everything is changing in the bio-world.

It is not only in the world of biology where scientists think about change and constancy. In the next section we consider an example from the world of physics.

\section{The importance of constancy in some physical theories}

According to Strauss (2009:411), a proper elaboration of the insight that change presupposes constancy, can be found in Galileo's formulation of the law of inertia and in Einstein's theory of relativity. The core of Einstein's theory primarily emphasises constancy (of the velocity of light in a vacuum). This means that whatever is in motion moves relatively to an element of constancy (Strauss 2009:411). Furthermore, for Einstein, the distinction between the kinematic and physical aspects of reality is related to the difference between reversibility and irreversibility (Einstein 1959:43; cf. Strauss 2011:6-7). This enables Einstein to reject the viewpoint that all physical processes are reversible and thus reducible to mechanistic movement (Strauss 2011:7). Galileo's insights and formulation of the law of inertia is revisited below. Before then, it is time to consider the nature of change and

10.Strauss (2009:111, fn. 1) points out that this assumption greatly influences Darwin's use of language. The terms 'constancy' (2) or 'persistence/persistently' (3) occur in a total of five instances in his work (Darwin 1869), whereas terms like 'change' in a total of five instances in his work (Darwin 1869), whereas terms like 'change'
(268), 'variation' (281) and 'variations' (162) occur much more frequently (number of occurrences indicated in brackets). constancy as understood in the reformational tradition, in order to provide an alternative view that offers a valuable contribution towards solving the issue.

\section{Attempts at integration: A reformational perspective}

In the reformational tradition, two dimensions delimit what we can experience and therefore constitute the horizon of experience, namely modal aspects (so-called functions, aspects or modalities) and concrete (natural and social) entities (Strauss 2009:67). The dimensions cohere so that the modal aspects are 'universal, constant, functional frameworks at the basis of all entitary functioning and thus co-conditions the occurrence of all kinds of events' (Strauss 2009:67, 68-71). Apart from the relationship between the two dimensions, the modal aspects themselves also cohere with one another. In order to understand this inter-modal coherence, we must first explore the structure of the modal aspects. If change and constancy are respectively seated in two of the modal aspects, this line of argumentation can lead to demonstrating that change and constancy also cohere. This is done by proposing a synopsis of the views of Dooyeweerd, Strauss and Hart in which the eventual differences between them are neglected, in an attempt to show my own position.

\section{The characteristics of modal aspects}

In Dooyeweerd's (1979:40-41) ontology, created reality displays several modes (i.e. aspects or modalities) in the temporal order. Although the modes are irreducible to each other, they have analogical coherence. Dooyeweerd distinguishes between the numerical, spatial, kinematic, physical, biotic, psychical, logical, historical, lingual, social, economical, aesthetic, judicial, ethical and certitudinal modes of being. These modes of being can be understood as having the following characteristics:

1. Aspects have ontic status as universal functional modes of existence (belonging to a distinct dimension) and this means that aspects are neither functions nor properties of things (Hart 1984:198-201; Strauss 2006:64-69). According to Hart (1984:85-134), modal aspects cohere with the dimension of entities without being 'dependent' upon those entities for their irreducible 'dimensional' existence. This means that the dimension of modal aspects co-determines the existence of entities (and events) in the sense that the latter invariably function within them. Furthermore, whenever entities or events function within a particular modal aspect, the unqualified universal meaning of the aspect requires a specification that is 'coloured' by the entity-structure of the entity function within the mode (Strauss 2009:143).

2. The difference between aspects and entities implies that there are two distinct kinds of laws: (1) 'laws for aspects' (universal modal laws) and (2) 'laws for entities' (type laws) (Strauss 2009:25). In general, it can be said that modal laws hold for all possible classes of entity, whereas type laws hold for a limited class of entity only (Strauss 2009:79). 
3. According to Dooyeweerd (1955:1:42-43), objective qualities that are ascribed to things in the logical and post-logical aspects are related to the subjective functions of human nature. They are related in such a way that the typical structure of the individuality of the thing (which is characterised by a specific relationship to its qualifying function) finds expression. Dooyeweerd (1955:1:43) uses the example of a bird's nest (characterised by a specific relation to animal life), which remains a bird's nest with respect to its objective logical characteristics and even if it is a possible object of human culture, symbolic signification, or aesthetic appreciation (Hart 1984:221-242).

4. As a result of (3), we can distinguish between the norm side and the factual side within each aspect of reality (Strauss 2009:76).

5. The factual side of aspects comprises the subject-subject and subject-object relationships, although the first aspect is an exception to this, since it has only subject-subject relationships (Strauss 2009:76-77).

6. Every modal aspect is fitted into a cosmic time order (Hart 1984:149ff.), whilst bringing to expression (in its own modal structure) a functionally 'coloured' manifestation of 'cosmic time'. On the law side, it expresses itself as time order and on the factual side as time duration (Strauss 2009:77). The duration remains constantly subjected to the time order, so that, for example, in the aspect of organic life, one finds the temporal order of birth, maturing, adulthood, ageing and dying in most higher organisms (Dooyeweerd 1955:1:28).

7. Each modal aspect has a core meaning (designated as its meaning nucleus or meaning kernel), which makes the modal aspect irreducible, indefinable and irreplaceable, since it founds the sphere sovereignty of every aspect (Strauss 2009:74-75). For Dooyeweerd (1979:43) this principle of sphere sovereignty is a creational principle connected with the scriptural ground motive of the Christian religion.

The above characteristics help us to understand the diversity between the aspects. According to Dooyeweerd (1955:2:74) full justice ought to be done to the specific sphere-sovereignty of the modal law-spheres, because each of the law-spheres is a temporal, modal refraction of the religious fullness of meaning. This means that every aspect accesses the whole of temporal coherence of meaning in its own modal structure. However, although the aspects are diverse, they also cohere with one another (Hart 1984:164). In the next section, we will see how this is possible.

\section{The interrelatedness of modal aspects}

The coherence between the modal aspects can be explained as follows:

1. Aspects are analogically related through moments of coherence with other aspects reflected within the structure of the particular aspect (Strauss 2009:75; Hart 1984:162 163). This means that the meaning of an aspect comes into expression only in this coherence. This feature is called the sphere universality of each aspect (Strauss 2009:76).
2. There is an order of succession amongst the modal aspects (Hart 1984:190-198). This means that the modal aspects are fitted into a cosmic order such that some are foundational to others' (Strauss 2009:170). For example, ${ }^{11}$ both the numerical and the spatial aspects are presupposed within the structure of the kinematic aspect (2009:163). Hart (1984:151) designates the direction going through the modal order from lower to higher modes as the founding direction of the order. Here the lower level functions in a foundational way as support for the existence of the higher levels. In contrast, the developmental direction refers to the order in which lower functioning is enriched as a result of its being made serviceable to a higher order (Hart 1984:152).

3. The moments of coherence between the modal aspects are referred to as analogies, ${ }^{12}$ which embrace both retrocipations (backwards pointing towards coherence between an aspect and earlier aspects in the cosmic order of time) and anticipations (forward-pointing coherence towards aspects later in the order) (Strauss 2009:75).

4. Furthermore, regarding the relationship between the sphere sovereignty (diversity) and sphere universality (coherence) of the aspects, Dooyeweerd maintains the following:

5. Sphere sovereignty can be maintained within the temporal inter-modal coherence of the different aspects only if the modal meaning of each law-sphere has a structure: law-spheres must have a nucleus guaranteeing the sphere sovereignty of the entire aspect. This nucleus must be surrounded by a number of analogical modal moments which partly refer backwards to the nuclei of other aspects and partly refer forward to aspects that are later in the cosmic arrangement (Dooyeweerd 1955:2:75; cf. Hart 1984:162).

In order to understand the significance of the theory of modal aspects for the ontological relationship between change and constancy, we first have to determine where the latter (respectively) are seated in the modal aspects. This is investigated in the next section.

\section{Change and constancy as modal kernels of meaning}

In defining the meaning nucleus of the kinematic aspect, Strauss (2009:89) once more refers to Galileo's experimental derivation of the law of inertia. The experiment rests on the hypothesis that whatever moves will continue its movement endlessly. This means that, whereas uniform motion does not need a cause, a change of motion requires an energyinput (physical cause) for both acceleration and deceleration. According to Strauss (2009:89), movement is something original in a functional sense and our immediate experiential awareness of uniform motion captures the meaning of

11.According to Strauss (2009:163), Galileo used a thought experiment in 1638 in which he contemplated the movement of a body on a path extended into infinity. I agree with Strauss that here the terms 'path' and 'extended' designate the spatial foundation of the kinematic aspect, whereas the term 'infinity' captures its numerical foundation.

12. Concrete examples of this can be found in composite expressions such as emotional strength (sensitive and physical aspects), economic trust (economic and certitudinal aspects) and aesthetic expression (aesthetic and lingual modes) 
movement as constancy. Therefore, we may adopt the synonym constancy when designating the meaning nucleus of the kinematic aspect.

When it comes to the term change, however, we need to look to the physical aspect of reality. According to Strauss (2009:89) energy in all its forms always causes physical changes. This means that energy-operation (the nucleus of the physical aspect) entails the cause-effect relationship and forms the basis of causality in its original sense. Cause and effect always implies change. Terms like 'change' or 'dynamics', inasmuch as they are synonyms, may then be used to designate the nuclear meaning of the physical mode.

\section{Change and constancy are interrelated}

In the previous section we saw that constancy is seated in the kinematic aspect, whereas change belongs to the physical aspect of reality. Since the kinematic and physical aspects are interrelated, it follows that constancy and change cohere as well.

The reason for this coherence is that change can be established only on the basis of something persistent and constant (Strauss 2009:13). Without an awareness of persistence, the very notion of change becomes problematic in the sense of the question (Strauss 2009:165): What is it that undergoes change? Here, it may be helpful to refer back to point (1) above: the meaning of an aspect (or its nucleus, for example, change) only comes into expression in the coherence with other aspects (or their nuclei, in this case constancy) reflected within the structure of a particular aspect (the physical, in our current case).

To make the case more concrete, we may borrow yet another example from Strauss (2009):

Suppose an ageing person claims that she has changed a lot during the past two decades. This statement only has meaning on the basis of an implicit awareness of persistence, for there is a constant reference to the same person. The relationship between change and constancy is therefore an example of the 'coherence of irreducibles. (p. 13)

Acknowledging the coherence of irreducibles between the kinematic and the physical aspects, opens up a new perspective in which constancy and change are no longer considered 'opposites' (Strauss 2009:166). An example from the natural sciences demonstrates the perspective. Let us consider the following statements:

1. The law of inertia assumes the constancy of motion if no physical forces interact with the movement under consideration.

2. The discovery of irreversible physical processes (e.g. radioactive decay) confirms the distinct and irreducible meaning of the physical aspect.

3. There exists an inter-modal connection between the kinematic and the physical aspects.

4. Should the above statements be true, there seems to exist an analogical moment within the physical aspect, which reminds us of the functional meaning of the kinematic aspect. This makes it possible to arrive at a more precise description of the law of energy conservation: we find an analogy of the kinematic aspect on the law side of the physical aspect (Strauss 2009:319).

\section{Conclusion}

An investigation of and a comparison between different philosophical traditions giving ontological primacy to change or constancy, shows that these conceptions cannot be regarded as satisfactory. Rather, change and constancy are coherent, irreducible dimensions of reality and therefore basic (primitive) ontological categories. Change refers to the physical aspect of reality, whereas constancy refers to the kinematic aspect. These two aspects cannot be reduced to each other, but can exist only in a relationship of coherence. This means that in epistemic frameworks, change and constancy go hand in hand, pointing towards the idea of plasticity. This can shed light on the discussions in previous articles, in particular in Loubser (2012), where a clarification of this topic was announced, to illustrate better what was argued in that context.

\section{Acknowledgements Competing interests}

The author declares that she has no financial or personal relationship(s) that may have inappropriately influenced her in writing this article.

\section{References}

Allen, R.E., 1966, Greek philosophy: Thales to Aristotle, The Free Press, New York.

Aristotle, 1941, 'Physics', transl. R.P. Hardie \& R.K. Gaye, in R. McKeon (ed.), The basic works of Aristotle, pp. 213-394, Random House, New York.

Darwin, C., 1869, On the origin of species by means of natural selection, or the preservation of favoured races in the struggle for life, John Murray, London.

Diels, H. \& Kranz, W., 1959-1960, Die fragmente der Vorsokratiker, vols. I-III, Weidmannsche Verlagbuchhandlung, Berlin.

Dooyeweerd, H., 1955, A new critique of theoretical thought, vols I-IV, transI. D.H. Freeman \& W. Young, Uitgeverij H.J. Paris, Amsterdam.

Dooyeweerd, H., 1979, The roots of western culture: Pagan, secular and Christian options, Wedge Publishing Foundation, Toronto.

Einstein, A., 1959, 'Autobiographical notes', in P.A. Schilpp (ed.), Albert Einstein philosopher-scientist, pp. 1-95, Harper Torchbooks, New York.

Freeman, K., 1971, Ancilla to the pre-Socratic philosophers: A complete translation of the Fragments in Diels Fragmente der Vorsokratiker, Basil Blackwell, Oxford.

Hart, H., 1984, Understanding our world: An integral ontology, University Press of America, Lanham.

Holton, G., 1978, The scientific imagination: Case studies, Cambridge University Press, Cambridge.

Loubser, R.A., 2012, 'Changes in epistemic frameworks: Random or constrained?' Koers - Bulletin for Christian Scholarship 77(2), 54-63. http://dx.doi.org/10.4102/ koers.v77i2.425

Loubser, R.A., 2013, 'Tracing some consensus on the nature of pre-scientific frameworks in philosophy of science', Acta Academica 45(2), 1-26.

Loubser, R.A., (in press), 'Factors shaping scientific framework change'.

Olthuis, J.H. \& De Graaff, A.H., 1978, Models of man in theology and psychology: Study guide, Institute for Christian studies, Toronto.

Plato, 1997, 'Cratylus', transl. C.D.C. Reeve, in J.M. Cooper \& D.S. Hutchinson (eds.), Plato: Complete works, pp. 101-156, Hackett Publishing Company, Indianapolis.

Strauss, D.F.M., 2005, 'Relativity and relativism: Historical and systematic considerations', Acta Academica 37(2), 199-231.

Strauss, D.F.M., 2006, 'The best known but least understood part of Dooyeweerd's philosophy', Tydskrif vir Christelike Wetenskap 42(1/2), 61-80. 
Strauss, D.F.M., 2009, Philosophy: Discipline of the disciplines, Paideia Press, Grand Rapids.

Strauss, D.F.M., 2011, 'Relasiebegrippe in die lig van die vraag oor of Einstein in die eerste plek ' $n$ "relatiwiteitsteorie" ontwikkel het' [Relation concepts in view of the question if Einstein in the first place developed a "thition], SuidAfrikaanse Tydskrif vir Natuurwetenskap en Tegnologie 30(1), 1-12. http://dx.doi. org/10.4102/satnt.v30i1.28
Vollenhoven, D.H.Th., 2005a, The problem-historical method and the history of philosophy, K.A. Bril (ed.), transl. J. De Kievit, S. Francke, J.G. Friesen \& R. Sweetman, De Zaak Haes, Amstelveen.

Vollenhoven, D.H.Th., 2005b, Wijsgerig woordenboek, K.A. Bril (ed.), De Zaak Haes, Amstelveen.

Von Varga, 1953, Einfuhrung in die erkenntnislehre: Die grundrichtungen und die grenzen der erkenntnis der wahrheit, Ernst Reinhardt Verlag, München/Basel. 